\title{
ENVIRONMENTAL AWARENESS AND ENVIRONMENTAL CITIZENSHIP DIMENSION
}

\author{
Anna Mravcová ${ }^{1}$
}

\begin{abstract}
The world development shows that global problems are still not being solved adequately. If we maintain this way of development the survival of humanity on the Earth will be impossible in future. In this context, the environmental awareness, disseminative global responsibility as well as environmental dimension of citizenship, are discussed today with the raising importance. In this paper we are going to examine and analyse the concept of environmental awareness. These empirically based facts will be reflected, analysed and put into the context with the environmental citizenship concepts. At the end we are going to present the results of the Eurobarometer surveys focused on the relationship of the EU citizens to environment and their environmental awareness and evaluate the current state in this area. The main findings have shown that environmental awareness of European citizens is raising, but it still does not have the appropriate level. This can have highly negative impact on the environment in this era of environmental crises and deepening environmental problems. Therefore, it is necessary to make serious steps to improve current situation, as environmental awareness is the precondition to achieve the change, which has to start from each individual.
\end{abstract}

KEY WORDS: Environmental Awareness, Environmental Citizenship, Environmental Responsibility, Global Problems, Special Eurobarometer Surveys.

\section{INTRODUCTION}

Environment is the focus of many discourses in various connotations today. One of the most common is the environmental crisis, which threatens the survival of humanity on Earth for future. Thus, the concept of environmental awareness, linked to environmental responsibility, is getting to the forefront. It puts a special appeal on the governments of the states or political elites of the international community in the direction of solving the global problems, but also on the individuals from who every change must come. Without their active approach the efforts for reaching sustainable development are not feasible. Environmental problems belong to the most

\footnotetext{
${ }^{1}$ Department of Social Sciences, Faculty of Economics and Management, Slovak University of Agriculture in Nitra, Tr. A. Hlinku 2, 94976 Nitra. E-mail: mravcova.anna@gmail.com
} 
serious global problems. They manifest themselves in the environmental crisis as a consequence of the human strategy of producing over-supply, its accumulation and consumption. The limits of natural resources and the ability of nature to absorb such created pollution have been already reached (Stahel, 2016, p. 111). Human has harmed the environment beyond acceptable measure, and only human can change this (in this context the Anthropocene discourse has been expanding today. It claims that human's impact on environment represents a new geological epoch (see more in Pallett, 2017; St'ahel, 2018). This has also significant impact on our environmental awareness, responsibility and environmental citizenship). To do this the adequate awareness is an inherent precondition.

This paper presents a study of a particular case study - it presents empirically based factual evidence in the centre of which is the environmental awareness. The results are reflected, analysed, and contextualize with the concept of citizenship and its shaping environmental dimension. The research is completed by the analyses of European Eurobarometer surveys focused on the relationship of EU citizens to the environment where we examine and analyse the level of environmental awareness of the EU citizens.

\section{IMPORTANCE OF ENVIRONMENTAL AWARENESS IN THE CURRENT WORLD}

Human has to recognize many interconnections he has today with the environment and the commitments to it, so that he does not excessively harm it, and provides himself and others with an appropriate living environment, thereby linking his privileges with the corresponding responsibilities (see also Krogman - Foote, 2011). Thus, he creates the environmental awareness and builds responsibility which are today crossing the national or regional borders and gain a global character. At the same time, they represent the basis for shaping the environmental citizen's approach.

Environmental awareness can be understood according to the UN as "the growth and development of awareness and understanding towards the biophysical environment and its problems, including human interactions and actions. Think "ecologically" or in terms of ecological consciousness" (UNESCO-UNEP, 1983). It comes from the individual, but its reach is wide. As a basis, we see the opportunity to acquire the knowledge, skills and attitudes needed to protect and improve the environment for us and for future generations. It develops and promotes new ways of positive action towards the environment among people in order to achieve 
environmental sustainability of the world. Building such awareness among people - citizens - is important in all aspects because it helps to look at the consequences of human actions globally, which can lead to the internal need to take environmental responsibility for the personal actions and decisions (as Stahel stated, mankind has entered the Anthropocene period - a philosophical situation when human can no longer take a favourable environment for the existence of civilization as a certainty, but he must take responsibility for the planetary environment and actively seek to maintain it (see more in Stahel, 2018, p. 11; for environmental responsibility see also St'ahel, 2015).

Environmental awareness, its dissemination, support and taking responsibility for one's actions, should represent the priorities for every civil society. The basis is to understand environmental problems, relationship between human and nature, own environmental behaviour, the sense of participation, the legal awareness about the environment, the attitude towards the environment around us and, in particular, that the environment is devastated by human. All these can lead to the need to participate in the change. Environmental awareness is developed at different levels, especially through education, direct experience, and observation on the basis of which human is creating own preferences.

This concept has not been clearly defined yet, but the environmental awareness of citizens is generally linked to the expression of their environmental literacy. Very simplistically, it is about recognizing the fragility of the environment and the importance of its protection. Its promoting is a key part of environmental action and achieving sustainability. Therefore, building the citizens' environmental awareness is becoming increasingly important in the context of the environmental crisis. But it is not just about creating a clean environment, but also about focusing on people's responsibilities towards respect for rights of human, nature, and life.

The main problem of current era can be therefore seen in low environmental awareness of citizens, which leads to the permanent damage to ecosystems. In this context, D. Goleman (2009) points to the need to develop the so-called ecological intelligence in relation to understand the benefits and potential threats in all civilization products. We think that today it is necessary to build this intelligence both on the individual and collective level. Environmental problems are directly or indirectly affected by people. Therefore, relationship between the perception of local environmental risks associated with consumption, local environmental awareness, and the recognition of shared environmental responsibility is 
important and so, individuals play a key role in improving the quality of environment.

Building citizens' environmental awareness requires also socio-political intervention in the form of various policies, strategies, goals and laws - so the support of the government or regional groupings as an important part of the environmental recovery.

\section{CITIZENSHIP AND ITS ENVIRONMENTAL DIMENSION}

Generally we can mark the citizenship as a concept that has unifying power and potential to connect people within a particular society. It is a so-called psychological dimension of citizenship (Carens, 2000, p. 166), which influences the power of the community's collective identity. From a historical point of view, the decisive core of citizenship is the possession of a formal membership status in a political and legal entity in which human has specific rights and obligations (Bellamy, 2014). This classical institute acquires several levels, especially legal, sociological, political or cultural. All form civil society. Citizenship is thus an important part of individual's identity and a precondition for avoiding political, social and cultural exclusion (see also Kastoryano, 2005). R. Bellamy (2008) considers citizenship as a prerequisite for civil equality giving its holders not only the same rights but also the obligations of a given political society. Such a term contains certain social quality and emphasizes equality in different areas.

\subsection{Environmental citizenship phenomenon}

For the features and positives of a civic concept, the term „environmental citizenship"is becoming increasingly commonplace today. In essence, this concept offers an escape from the classical differentiation of citizenship to citizens and non-citizens, thus promising a kind of universal inclusiveness and transnationality. It is a form of citizenship „over the nation state“, focused on the responsibility of people towards the world (UNESCO, 2014). It is a citizenship from a global perspective, a manifestation of behaviour that promotes justice in the principles of interdependence in the world, equality of human beings, and shared responsibility for solving global problems (Carabain et al., 2012).

The strength of civil institute as such consists in the fact that if many citizens show a strong sense of belonging to the same community, social cohesion is strengthened and a strong identity can motivate others to 
participate actively in society. Therefore, in the context of globalization and ongoing environmental crisis, increasing emphasis has been placed on shaping global - and also in particular environmental - dimensions of citizenship.

In order to bring environmental citizenship closer to people, the argument relevant to all is appropriate - we are all inhabitants of the same planet - its sustainability and productivity are important to everyone. To take environmental citizen's attitude people must understand that they are part of a global entity and must perceive not only themselves and their surroundings, but seek to a global view of their existence.

So far, the notion of environmental citizenship has no clear definition. However, we agree with the opinion of $\mathrm{H}$. Pallet that it is about the connection of two concepts - „environment „and „citizenship“(Pallet, 2017), which links the fundamental content of citizenship characterized by rights and obligations to a particular community and the environment which is surrounding this community. On the other hand, this concept can be understand in the broad sense which defines it on the basis of the relationship of individual and the common good (Dobson, 2007).

Most of the existing definitions of this term tend to emphasize obligations over the rights, to question in some way the geographical definition of the community to which the citizen belongs, and to require the cultivation of specific skills and values, especially environmental awareness and literacy. But, who is an environmental citizen? Difficult and deep discussions on this term are held in a various professional discourses. However, in summary, we understand the environmental citizen as someone who is aware of both environmental issues and his responsibility to participate in their solving. Awareness and responsibility are an important prerequisite and basis for environmental citizenship. But it means more. Environmental citizen has to perceive that he is part of not only a particular social entity or state, but that he is part of something bigger - a global society - surrounded by its environment which development he affects. Environmental citizen is someone who identifies himself as part of a developing global society and whose action is beneficial to its development (Israel, 2012).

Similar views of the environmental dimension of citizenship were held by a number of eco-philosophy and eco-ethics representatives, long time before the current active use of this term. For example, A. Leopold points out that man today has not only belonging to a certain social entity, but also the so called "biotic community" - to a particular society and to its surrounding environment and he must behave adequately to this. According to Leopold, 
the development of ecological conscience changes the role of human from the conqueror of nature to his ordinary member (Leopold, 1999). Similar opinion has A. Naess. In his deep ecology he prefers the perception of human as a part of nature and all relationships, the whole of which make up the biosphere. Human is dependent on nature and he is a part of it. The aim of his deep ecology is a comprehensive change of the way of life and organization of human society, its values, priorities and imperatives - the transformation from anthropocentrism to biocentrism (Naess, 1989), where harmony with the environment is the foundation of human activities.

We understand environmental citizenship as a phenomenon that's aim is to redefine the relationship between human and nature, emphasizing that environmental protection is the responsibility of everyone and is based on life choices, while minimizing the negative impact on it (see also Meeraha et al., 2010). It focuses on changing people's attitudes and behaviour towards the environment, as well as promoting personal participation. It means a self-identification with a certain system of moral values and an internal attitude based on adequate environmental awareness, which is a question of personal experience, but also a question of informedness, education, and the ability to take responsibility for own actions also in the environmental level. This term thus expresses "the responsible pro-environmental behaviour of citizens who participate in society as representatives of changes in the private and public sphere in local, national, and global dimensions through both individual and collective action to address environmental problems, prevent new problems, achieve sustainable development, as well as a healthy relationship towards nature" (ENEC, 2018).

We also connect the environmental citizenship with rights and obligations. However, it is a different category of rights - environmental - and an obligation to recognize that others should also have the same rights. Therefore, human responsibility is not only about protecting the environment, but also about not possessing more than to what he has the right. Thus, we associate environmental citizenship with the duty to look further than to satisfy own immediate interests and to take into account the welfare of the wider society as well as the needs of future generations (see more in Barnett et al., 2005).

The urgency of the issue and the interconnection of environmental citizenship with the negative consequences of globalization is unmistakable. Therefore, reference to this dimension of citizenship shall not absent in any area. Nevertheless, the environmental dimension of insight into citizenship still absents in many discourses or it is at the end of their interest. However, 
environmental problems have been coming to the forefront everywhere and have becoming a necessary part of the current global society, individual states, individual lives. People have to be able to assess the pace of human impacts and the recovery of ecosystems, and understand the need to set limits. Earth limits have already been exceeded and it is necessary to think beyond the present (see also Mravcová - Šeben Zat'ková - Pechočiaková Svitačová, 2017).

\section{ANALYSES OF THE EU CITIZENS' ENVIRONMENTAL AWARENESS}

The EU focuses its surveys also on the environment where it examines the relationship that EU citizens have to it. In this part, we will pay attention to the development of this relationship in selected Eurobarometer surveys. We will examine and analyse the state of their environmental awareness and responsibility, as the preconditions for taking on environmental citizenship and compare the development of individual periods at the same time. Our analysis is focused on the special Eurobarometers that the European Community has started to realize since 1982 about every three years. The analysis includes data from last six surveys conducted in the EU countries. We decided to analyse surveys after the adoption of the Millennium Development Goals (2000) - in the time when the common goals for governments and for entire mankind were already set. Therefore, the first analysed survey was the survey from the end of 2002. Moreover this was also the period after the adoption of the Sixth Environment Action Programme of the European Community (2002), which was focused on promoting the integration of environmental interests into all EU policies and the dissemination of environmental awareness among people, and the achievement of sustainable development in the EU countries. The second survey was conducted in the autumn 2004, shortly after the biggest enlargement of the Union, which certainly supported the interest to explore our issue within such a large group of diverse countries. At the same time, several important international events were held to achieve sustainable development, with at least informational reach on a wide range of citizens, so the awareness in this area could grow. The third survey was carried out in the end of 2007, shortly before the outbreak of the global economic crisis and in the mid-term of achieving the Millennium Goals, which had not been delivering adequate results. The fourth survey was conducted in spring 2011. It was a period when all EU countries were more or less negatively affected by the economic crisis and many were solving even existential problems. We 
assume that at that time the environment was not as important to humans as it was in "normal“circumstances. The fifth survey was realized in spring 2014. It was a relatively stable period when the negative effects of the economic crisis were already fade-away, and at the same time, the migration crisis had not irrupted yet, which could again break people away from their normally preferred values. It was also a period of intensive preparation of the new development goals, because it was already clear that the Millennium ones will not be achieved until 2015. The last survey was conducted in the autumn 2017. Again, this was a relatively stable period when the countries already overcame the worst effects of both crises. Simultaneously, it is the period after the adoption of the Sustainable Development Goals (2015) and new action plans and strategies, when environmental issues and their urgency are still more intensively emphasized in the media. People gain a lot of information. However, the catastrophic consequences to which mankind's actions lead are still not emphasized adequately.

Table 1: Selected Eurobarometer questions' results

\begin{tabular}{|c|c|c|c|c|c|c|}
\hline \multirow{2}{*}{ Examined question } & \multicolumn{6}{|c|}{$\begin{array}{c}\text { Percentage of positive responses for a given } \\
\text { period }\end{array}$} \\
\hline & $\begin{array}{l}\text { E180/ } \\
2002\end{array}$ & $\begin{array}{c}\text { E217/ } \\
2004\end{array}$ & $\begin{array}{c}\text { E295/ } \\
2007\end{array}$ & $\begin{array}{c}\mathrm{E} 365 / \\
2011\end{array}$ & $\begin{array}{c}\text { E416/ } \\
2014\end{array}$ & $\begin{array}{c}\text { E468/ } \\
2017\end{array}$ \\
\hline $\begin{array}{l}\text { Do you consider protecting } \\
\text { the environment persona- } \\
\text { lly important? }\end{array}$ & - & - & 96 & 95 & 95 & 94 \\
\hline $\begin{array}{l}\text { What is the first you think } \\
\text { about when you hear the } \\
\text { notion „environment“? } \\
\text { - nature protection } \\
\text { - the state of the environ- } \\
\text { ment our children will } \\
\text { inherit } \\
\text { - polluted towns and cities } \\
\text { - climate change } \\
\text { - green and nice nature }\end{array}$ & $\begin{array}{c}14 \\
25 \\
- \\
11\end{array}$ & $\begin{array}{c}17 \\
25 \\
- \\
11\end{array}$ & $\begin{array}{l}12 \\
22 \\
19 \\
13\end{array}$ & $\begin{array}{l}17 \\
14 \\
13 \\
13 \\
10\end{array}$ & $\begin{array}{l}- \\
- \\
- \\
-\end{array}$ & $\begin{array}{l}- \\
- \\
- \\
- \\
-\end{array}$ \\
\hline $\begin{array}{l}\text { What environmental issues } \\
\text { are you most afraid of? } \\
\text { - climate change } \\
\text { - polluted air } \\
\text { - growing amount of waste } \\
\text { - water pollution } \\
\text { - agricultural pollution and } \\
\text { soil degradation }\end{array}$ & $\begin{array}{c}39 \\
44 \\
- \\
43 \\
-\end{array}$ & $\begin{array}{l}45 \\
45 \\
30 \\
47 \\
26\end{array}$ & $\begin{array}{l}57 \\
40 \\
24 \\
42 \\
23\end{array}$ & $\begin{array}{l}34 \\
36 \\
33 \\
41 \\
25\end{array}$ & $\begin{array}{c}- \\
56 \\
43 \\
50 \\
29\end{array}$ & $\begin{array}{l}51 \\
46 \\
40 \\
36 \\
34\end{array}$ \\
\hline
\end{tabular}




\begin{tabular}{|c|c|c|c|c|c|c|}
\hline $\begin{array}{l}\text { What is the best source of } \\
\text { information about environ- } \\
\text { mental issues? } \\
\text { - television } \\
\text { - internet a social networks } \\
\text { - newspapers }\end{array}$ & $\begin{array}{c}81 \\
6 \\
52\end{array}$ & $\begin{array}{l}72 \\
11 \\
51\end{array}$ & $\begin{array}{l}68 \\
24 \\
43\end{array}$ & $\begin{array}{l}73 \\
31 \\
41\end{array}$ & $\begin{array}{l}65 \\
41 \\
37\end{array}$ & $\begin{array}{l}71 \\
42 \\
26\end{array}$ \\
\hline $\begin{array}{c}\text { Do environmental issues } \\
\text { have a direct impact on } \\
\text { daily life and health? }\end{array}$ & - & 72 & 78 & 76 & 77 & 81 \\
\hline $\begin{array}{l}\text { Can the individual play an } \\
\text { important role in environ- } \\
\text { mental protection? }\end{array}$ & 43 & - & 86 & 87 & 85 & 87 \\
\hline $\begin{array}{c}\text { What environmental } \\
\text { activities have you recently } \\
\text { practiced? } \\
\text { - separation of waste for } \\
\text { recycling } \\
\text { - buying local products } \\
\text { - reducing energy con- } \\
\text { sumption } \\
\text { - reducing disposable } \\
\text { products consumption } \\
\text { - reducing water consump- } \\
\text { tion } \\
\end{array}$ & $\begin{array}{l}- \\
- \\
- \\
-\end{array}$ & $\begin{array}{l}- \\
- \\
- \\
-\end{array}$ & $\begin{array}{l}59 \\
21 \\
47 \\
\\
30 \\
37\end{array}$ & $\begin{array}{l}66 \\
28 \\
53 \\
\\
37 \\
43\end{array}$ & $\begin{array}{c}72 \\
35 \\
52 \\
- \\
37\end{array}$ & $\begin{array}{l}65 \\
43 \\
35 \\
\\
34 \\
27\end{array}$ \\
\hline $\begin{array}{l}\text { What should be the EU's } \\
\text { highest environmental } \\
\text { priorities? } \\
\text { - waste recycling } \\
\text { - reducing households } \\
\text { energy consumption } \\
\text { - increasing the use of pub- } \\
\text { lic transport } \\
\text { - waste reduction } \\
\text { - buying local products }\end{array}$ & $\begin{array}{l}- \\
- \\
- \\
-\end{array}$ & $\begin{array}{l}72 \\
39 \\
30 \\
32 \\
-\end{array}$ & $\begin{array}{l}55 \\
47 \\
38 \\
30 \\
20\end{array}$ & $\begin{array}{l}59 \\
48 \\
37 \\
32 \\
26\end{array}$ & $\begin{array}{l}54 \\
39 \\
39 \\
24 \\
22\end{array}$ & $\begin{array}{l}- \\
- \\
- \\
-\end{array}$ \\
\hline $\begin{array}{l}\text { Should the major polluters } \\
\text { have primary responsibili- } \\
\text { ty for improvement? }\end{array}$ & - & - & 90 & 91 & 93 & 94 \\
\hline $\begin{array}{l}\text { What should the EU do for } \\
\text { this purpose? } \\
\text { - introduce higher fines for } \\
\text { polluters } \\
\text { - ensure higher financial } \\
\text { incentives for those who } \\
\text { protect the environment } \\
\text { - inform about environ- } \\
\text { mental issues } \\
\text { - afforce existing legislative } \\
\text { - introduce exclusive or } \\
\text { increased taxation of envi- } \\
\text { ronmental harmers }\end{array}$ & $\begin{array}{l}14 \\
45 \\
40 \\
36\end{array}$ & $\begin{array}{l}25 \\
44 \\
45\end{array}$ & $\begin{array}{l}29 \\
30 \\
33\end{array}$ & $\begin{array}{l}26 \\
26 \\
25 \\
15\end{array}$ & $\begin{array}{r}33 \\
31 \\
30 \\
18\end{array}$ & $\begin{array}{l}27 \\
28 \\
31 \\
\\
22\end{array}$ \\
\hline $\begin{array}{l}\text { Do big companies and in- } \\
\text { dustry enough for environ- } \\
\text { mental protection? }\end{array}$ & - & - & - & 79 & 77 & 79 \\
\hline
\end{tabular}




\begin{tabular}{|c|c|c|c|c|c|c|}
\hline $\begin{array}{l}\text { Do citizens enough for en- } \\
\text { vironmental protection? }\end{array}$ & - & - & - & 69 & 65 & 66 \\
\hline $\begin{array}{l}\text { Do nation states enough } \\
\text { for environmental protec- } \\
\text { tion? }\end{array}$ & - & - & - & 72 & 70 & 67 \\
\hline $\begin{array}{l}\text { Does the EU enough for } \\
\text { environmental protection? }\end{array}$ & - & - & - & 63 & 56 & 61 \\
\hline $\begin{array}{c}\text { At what level should en- } \\
\text { vironmental decisions be } \\
\text { taken? } \\
\text { - at the EU level } \\
\text { - at the national level }\end{array}$ & $\begin{array}{l}33 \\
30\end{array}$ & $\begin{array}{l}33 \\
33\end{array}$ & $\begin{array}{l}67 \\
28\end{array}$ & $\begin{array}{l}64 \\
32\end{array}$ & $\begin{array}{l}60 \\
36\end{array}$ & $\begin{array}{l}67 \\
29\end{array}$ \\
\hline $\begin{array}{c}\text { What should EU improve in } \\
\text { the environmental area? } \\
\text { - control the proper imple- } \\
\text { mentation of environmen- } \\
\text { tal laws } \\
\text { - help third countries im- } \\
\text { prove their environmental } \\
\text { standards } \\
\text { - create environmental } \\
\text { legislation that is impor- } \\
\text { tant for environmental } \\
\text { protection } \\
\end{array}$ & - & - & $\begin{array}{c}- \\
80 \\
82\end{array}$ & $\begin{array}{c}- \\
79 \\
81\end{array}$ & $\begin{array}{l}79 \\
74 \\
77\end{array}$ & $\begin{array}{l}83 \\
82 \\
80\end{array}$ \\
\hline $\begin{array}{l}\text { Do you agree to invest } \\
\text { more money in environ- } \\
\text { mental protection? }\end{array}$ & - & - & 78 & 89 & 84 & 85 \\
\hline $\begin{array}{c}\text { Do you feel well informed } \\
\text { about environmental } \\
\text { issues? }\end{array}$ & - & 48 & 55 & 60 & 62 & - \\
\hline $\begin{array}{l}\text { In what area do you feel } \\
\text { lack of information? } \\
\text { - impact of chemicals in } \\
\text { products on health } \\
\text { - soil degradation } \\
\text { - wasting of natural re- } \\
\text { sources } \\
\text { - water pollution } \\
\text { - agricultural pollution } \\
\text { - loss of biodiversity } \\
\text { - climate change } \\
\end{array}$ & $\begin{array}{l}- \\
- \\
- \\
- \\
- \\
- \\
-\end{array}$ & $\begin{array}{c}41 \\
- \\
29 \\
27 \\
29 \\
29 \\
26\end{array}$ & $\begin{array}{c}36 \\
- \\
26 \\
27 \\
28 \\
26 \\
26\end{array}$ & $\begin{array}{l}40 \\
27 \\
27 \\
28 \\
29 \\
27 \\
20\end{array}$ & $\begin{array}{c}39 \\
29 \\
28 \\
28 \\
28 \\
25 \\
-\end{array}$ & $\begin{array}{l}- \\
- \\
- \\
- \\
- \\
-\end{array}$ \\
\hline $\begin{array}{l}\text { Can environmental pro- } \\
\text { tection support economic } \\
\text { growth? }\end{array}$ & - & - & - & 83 & 74 & - \\
\hline $\begin{array}{l}\text { Should environmental } \\
\text { criteria be equal to econo- } \\
\text { mic and social in assessing } \\
\text { national progress? }\end{array}$ & - & 85 & 67 & 55 & 59 & - \\
\hline
\end{tabular}

Source: Own processing according to the Special Eurobarometer Surveys (European Commission, 2002; 2005; 2008; 2011; 2014; 2017). 


\subsection{Evaluation of surveys in the context of environmental awareness and citizenship}

From the data analysis of selected Eurobarometer surveys on the attitude of European citizens to the environment, we can say that the citizens of the Union are quite aware of environmental problems. Although there is no significant grow in the analysed attributes and results when we compare individual examined periods. The growth was noticed only in several areas. On the other hand, several areas assigned also small decrease.

In the last four surveys the question was asked at the beginning, whether EU citizens consider personal protection of their environment to be important. Already on the basis of more than $90 \%$ of positive responses in all surveys, we can see some degree of awareness almost among all respondents. When it comes to the question of what EU citizens first think when they hear term environment, the development of answers does not change significantly and in the last two surveys this question was not presented. The most common answers were: nature protection; the state of the environment our children will inherit; polluted cities. All surveys find out of which environmental problems EU citizens are most afraid. Here we see some development. While in 2002 it was mainly a threat of nuclear energy and radioactive waste, problems that resonate more and more in society have gradually come to the forefront. The most feared are: climate change (2017 - 51\%); air pollution (2017 - 46\%); increasing amount of waste $(2017-40 \%)$. Today, people are worried about the problem of water pollution least among all selected surveys (2017 - 36\%). We also see that EU citizens still receive the most information about environmental issues from television, although this value is slightly decreasing (2017 - 71\%). The second place have the Internet and social networks (2017 - 42\%). This resource is gaining importance because of quick and easy access to information.

It is positive to note that Union citizens are aware that environmental problems have a direct impact on their daily lives and health. This value gradually increased to $81 \%$. This can be an important prerequisite for citizens to be really active for a real change. The awareness that every individual can play an important role in solving environmental problems contributes significantly to our research too. Also this view evolved. In $200265 \%$ of respondents said that although they were trying to care for the environment, it wouldn't make sense until everyone do it, and only $12 \%$ said they were taking care of the environment and it had an impact. In 2017, up to $87 \%$ of 
EU citizens think that change comes from the individual. We consider this as a strong basis for awareness and assumption of accepting environmental responsibility. The other question is connected with this - what positive activities they have done themselves in favour of the environment recently. On the basis of the answers, we can say that citizens are actively trying to protect and improve the environment, especially in the areas that are most emphasized in the media. Mostly, they separated waste for recycling (2017 - 65\%); bought local products (2017 - 43\%), and reduced energy consumption (2017 - 35\%). Furthermore, they reduced the use of disposable products including bags (2017 - 34\%), reduced water consumption although it was lower than expected; and used environmentally more friendly ways of traveling. Subsequently, respondents commented on what the EU's priorities for environmental protection should be. Those should be mainly: support for recycling (2014 - 54\%); reducing energy consumption of households (2014 - 39\%); increasing the use of public transport (2014 $39 \%$ ); or reducing waste; support for buying local products. Reducing water consumption occurred only in 2014 and reached just $14 \%$, which is not a positive finding, as the lack of clean and drinking water is one of the major global problems. We can see that the activities that citizens themselves do consider themselves also as priorities in solving problems.

In the next question, they almost unanimously agreed that the greatest polluters of the environment should bear the greatest responsibility for its improvement. In the latest survey, up to $94 \%$ of respondents agree with this. For this purpose, they also propose EU to increase fines for these polluters. However, this option reached its lowest level in 2017. Furthermore, that the EU should offer higher financial incentives for those who protect the environment. It is essential for us that citizens want to raise their awareness of environmental problems, but this response has reached only $28 \%$ last time. Then, they propose to strengthen existing legislation, because they perceive that there are many of those who are harming the environment beyond the respectable level and they do not take responsibility for this. Some citizens also like the possibility of imposing higher taxes on those who harm the environment. It is positive that people perceive this issue and are interested in contributing to the change.

When asked whether the individual participants are doing enough to improve and protect the environment (the last three surveys), the answers have shown that no one is doing enough. Neither large companies and industry (2017 - 79\%) nor national governments (2017 - 67\%), nor the EU (2017 - 61\%), nor citizens (2017 - 66\%). However, this could be a 
good impulse for self-reflection to make more effort in this respect, to raise awareness, and to act more proactively on behalf of the environment. However, in all surveys, citizens agree that environmental decisions should be taken jointly at the EU level. Since this is the issue affecting all people, it is important to prevent some members from not respecting international needs (this option has dominated since 2007).

The high level of EU citizens' inclination has also been seen in the surveys to the opinion that the Union should help non-member countries to improve their environmental standards $(2017-82 \%)$. We see the awareness of the global character of environmental problems and of the need for each country to approach them actively and responsibly. Simultaneously, they consider important for the EU to work towards environmental legislation (2017 $80 \%$ ), while favouring that the EU should be able to control how member states apply this legislation (2017 - 83\%). For this purpose, more than 4/5 of respondents agree to spend more money on environmental protection and are willing to pay more for environmentally more friendly products.

Between 2004 and 2014, awareness of environmental issues was also examined, where relatively high percentage of people agreed they felt sufficiently informed about these problems (2014-62\%). This was also indirectly reflected in the 2002 survey, where citizens declared sufficient or adequate information on individual issues. The fact that in many areas they would like to increase their awareness also points to the interest in this issue. It concerns in particular: soil degradation (2014 - 39\%); waste of natural resources (2014 - 29\%); water pollution (2014 - 28\%) or agricultural pollution (2014 - 28\%). Climate change did not occur in the 2014 survey and reached only $20 \%$ in 2011 . Nevertheless, the reality encourages us to believe that people still do not have enough information about this problem and its consequences have not been so direct up to now to realize its real seriousness.

According to EU citizens (2011 and 2014 surveys), effective environmental management and its protection can lead to economic growth. However, economic growth is associated with increasing consumption, production, etc. Therefore, we more tend to reduce the economic growth considerably in order to achieve sustainable development. Simultaneously, respondents are aware of the importance of environmental factors. In 2014, almost 3/5 stated that these should have the same weight in assessing national progress as economic and social ones (2004 to $85 \%$ ).

The last survey did not include several questions from previous years, but showed that up to $87 \%$ of respondents are afraid of the impact of plastics to the 
environment. It also focuses on the problem of polluted air. Almost half of the respondents stated that the air condition had become worse over the last 10 years. Up to $41 \%$ think it is necessary to introduce stricter rules and controls in this regard, and at the same time provide more information - 28\%. For this purpose, citizens themselves limit the use of cars, change home appliances to more energy saving, etc. But up to $35 \%$ said they were doing nothing. This passivity and apathy is a serious problem. Thus, although EU citizens have significant degree of environmental awareness and its level is developing in a positive direction, they still do not apply this awareness sufficiently in their lives. Although they are taking more and more positive actions, they still need to gain deeper insight into the negative consequences of human action towards the environment, so that they can address these issues as responsible citizens, contribute actively to the sustainability of development, and do not focus their actions only on the trends from the media.

The presented analysis has helped us to look at the level of environmental awareness of EU citizens, their attitude towards the environment, and their demands for political elites for change in the direction towards sustainability. The results point to the relatively positive development and adequate outlook - to the increasing awareness and ability to identify environmental problems and risks in many areas, as well as to take an active approach to addressing them. But in many areas this awareness is still low. Therefore, we assume that its level is still not sufficient. People are not able to accept environmental responsibility for their behaviour enough to set strict limits for their actions, lives, and well-being in the long term. As the problem we also perceive the fact that people are still not sufficiently aware of the seriousness of the problems, as well as of their belonging to the common planet that is endangered by humans and only humans can change this. However, people have many opportunities to act as environmental citizens in different directions in relation to their local, national, and global environment. Local initiatives have a particular potential. According to Dobson, every human act has an environmental impact on the public, including the local one (like we live, draw resources, create waste, etc.). The aim of environmental citizens is to minimize a negative footprint and live sustainably so that others can live well (Dobson, 2007, pp. 280 - 282).

\section{CONCLUSION}

Environmental awareness, taking environmental responsibility and shaping environmental citizenship, as well as understanding the personal 
and social environmental role in the world, is an important prerequisite for a shift towards achieving sustainability of the development of environment and the world. However, many improvements still need to be realized in this context, focused particularly to dissemination of information. Environmental awareness is a precondition for achieving change at all levels. Environmentally conscious citizens can legitimize innovations also in the environmental policy and decision-making, and set jointly defined limits of action towards the environment. The apathy based on unconscionability about global problems is not respectable from the long-term perspective for the world and it shall not be supported or accepted longer. Environmental awareness plays a crucial role in managing pro-environmental decisions and individual behaviour and human participation as well as activity is essential to solve environmental problems. Therefore we assume that giving people the chance to have the knowledge and skills to make decisions about their environment creates environmental benefits that cannot be achieved through common approaches.

We can see a considerable shift in the examined issue mainly in the meaning of education and informedness, when the knowledge and information are coming to the people from nearly every side and the consequences of environmental crises are still more visible. Therefore, our assumption was that the data about environmental awareness of the EU citizens from one survey to another will grow. But in fact there were no significant differences among the results of individual examined periods. The growth was noticed only in a few areas, although the last survey also showed the interest and worries about other intensifying problems. Thus we can say that there is still a need to strengthen the citizen's relationship to the environment and awareness of the responsibility they have towards it. This requires still deep efforts, which should focus in particular on promoting environmental education and awareness rising, engaging people in environmental problems solving in everyday life, promoting volunteering, as well as raising people's awareness of the real consequences of the environmental crisis.

\section{REFERENCES}

BARNETT, J. (et al.). (2005). Environmental citizenship: literature review. Bristol: Environment Agency, 2005.

BELLAMY, R. (2008). Citizenship. New York: Oxford University Press, 2008. 
BELLAMY, R. (2014). Citizenship: Historical Development. [online]. Available at: http://cadmus.eui.eu/bitstream/handle/1814/35878/Bellamy_ Citizenship_history.pdf. [Accessed 08-07. 2019].

CARABAIN, C. (et al.). (2012). Global Citizenship. From Public Support to Active Participation. Amsterdam: NCDO, 2012.

CARENS, J., H. (2000). Culture, Citizenship, and Community. A Contextual Exploration of Justice as Evenhandedness. Oxford: Oxford University Press, 2000.

DOBSON, A. (2007). Environmental Citizenship: Towards Sustainable Development. In: Sustainable Development, Vol. 15, 2007, pp. 276 - 285. DOI: $10.1002 /$ sd.344.

ENEC. (2018). Defining Environmental Citizenship. [online]. Available at: http://enec-cost.eu/our-approach/enec-environmental-citizenship/. [Accessed 28-06. 2019].

EUROPEAN COMMISSION. (2002). Special Eurobarometer 180. The attitudes of Europeans towards the environment. Brussels: European Union, 2002. EUROPEAN COMMISSION. (2005). Special Eurobarometer 217. Attitudes of European citizens towards the environment. Report. Brussels: European Union, 2005.

EUROPEAN COMMISSION. (2008). Special Eurobarometer 295. Attitudes of European citizens towards the environment. Report. Brussels: European Union, 2008

EUROPEAN COMMISSION. (2011). Special Eurobarometer 365. Attitudes of European citizens towards the environment. Report. Brussels: European Union, 2011.

EUROPEAN COMMISSION. (2014). Special Eurobarometer 416. Attitudes of European citizens towards the environment. Report. Brussels: European Union, 2014.

EUROPEAN COMMISSION. (2017). Special Eurobarometer 468. Attitudes of European citizens towards the environment. Report. Brussels: European Union, 2017.

GOLEMAN, D. (2009). Ecological Intellegence. New York: Broadway Books, 2009.

ISRAEL, R. (2012). Global citizenship: A Path to Building Identity and Community in a Globalized World. San Bernardino: Create Space Independent Publishing Platform, 2012.

KASTORYANO, R. (2005). Citizenship, Nationhood, and Non-Territoriality: Transnational Participation in Europe. In: PS - Political Science \& Politics. Vol. 10, 2005, pp. $693-696$. 
KROGMAN, N., FOOTE, L. (2011). Global Citizenship and the Environment: Embracing Life in All Its Forms. In: SHULTZ, L. (et al.). Global Citizenship Education in Post-Secondary Institutions. New York: Peter Lang, 2011, pp. $108-119$.

LEOPOLD, A. (1999). Obrázky z chatrče a rozmanité poznámky. Tulčík: Abies, 1999.

MEERAHA, T., S., M. (et al.). (2010). Environmental citizenship: What level of knowledge, attitude, skill and participation the students own? In: Procedia Social and Behavioral Sciences, Vol, 2, 2010, pp. 5715 - 5719.

MRAVCOVÁ, A., ŠEBEN ZAŤKOVÁ, T., PECHOČIAKOVÁ SVITAČOVÁ, E. (2017). Globálne občianstvo v terciárnom vzdelávaní. Nitra: SPU, 2017.

NAESS, A. (1989). Ekologie, pospolitost a životní styl. Tulčík: Abies, 1989.

PALLET, H. (2017). Environmental citizenship. In: RICHARDSON, D. (eds.). The International Encyclopedia of Geography: People, the Earth, Environment, and Technology. New Jersey: John Wiley \& Sons, 2017. https://doi.org/10.1002/9781118786352.wbieg0474.

SŤAHEL, R. (2015). Environmentálna zodpovednost' a environmentálna bezpečnost'. In: Filozofia, Vol. 70, No. 1, 2015, pp. 1 - 12.

SŤAHEL, R. (2016). Environmental Crises and Political Revolutions. In: ARNASON, J. P., HRUBEC, M. (eds.). Social Transformations and Revolutions. Edinburgh: Edinburgh University Press, 2016, pp. 99 - 120.

SŤAHEL, R. (2018). Environmentalizmus ako politická filozofia pre 21. storočie. In: Filozofia, Vol. 73, No. 1, 2018, pp. 1 - 13.

UNESCO. (2014). Global Citizenship Education. Preparing learners for the challenges of the $21^{\text {st }}$ century. Paris: UNESCO, 2014.

UNESCO-UNEP. (1983). International Environmental Education Programme, Glossary of Environmental Education Terms. Hungary: UNESCO, 1983. 